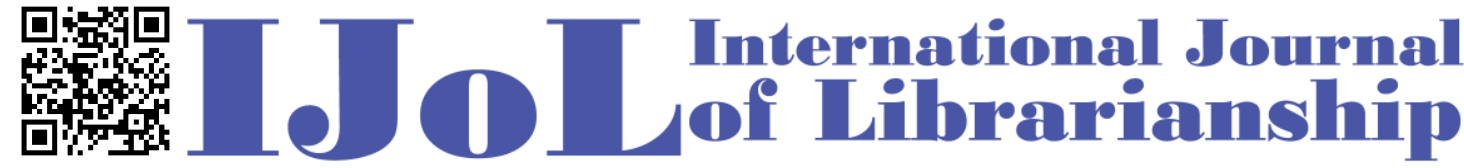

ISSN: 2474-3542 Journal homepage: http://journal.calaijol.org

\section{Embedded Information Literacy Instruction in the Mobile Environment: A Case Study}

\author{
Jinchi Guo and Han Zhu
}

\begin{abstract}
:
Information literacy instruction in various countries has expanded in a variety of ways. At universities, it has mainly taken the form of credit-based courses, lectures, and embedded instruction. While European and American universities carry out more embedded instruction, universities in China focus more on credit-based courses and lectures, leaving embedded instruction in an exploratory stage. This paper is a preliminary study of a research project that aims to investigate the department-based, embedded information literacy instruction among the libraries of 42 "Double-First Class" universities in China. Using East China Normal University Library as an example, this paper discusses the teaching mode, teaching philosophy, teaching design, teaching methods and contents in order to explore how embedded information literacy instruction can make use of the mobile Internet platform. The specific areas to be examined include teaching resources, enhancing classroom interactions, and after-class feed-pushing as part of teaching support. Finally, some recommendations are put forward for the extension and expansion of embedded information literacy instruction.
\end{abstract}

To cite this article:

Guo, J., \& Zhu, H. (2019). Embedded information literacy instruction in the mobile environment: A case study. International Journal of Librarianship, 4(2), 94-110.

To submit your article to this journal:

Go to http://ojs.calaijol.org/index.php/ijol/about/submissions 


\title{
Embedded Information Literacy Instruction in the Mobile Environment: A Case Study ${ }^{1}$
}

\author{
Jinchi Guo, Han Zhu \\ East China Normal University Library, Shanghai, China
}

\begin{abstract}
Information literacy instruction in various countries has expanded in a variety of ways. At universities, it has mainly taken the form of credit-based courses, lectures, and embedded instruction. While European and American universities carry out more embedded instruction, universities in China focus more on credit-based courses and lectures, leaving embedded instruction in an exploratory stage. This paper is a preliminary study of a research project that aims to investigate the department-based, embedded information literacy instruction among the libraries of 42 "Double-First Class" universities in China. Using East China Normal University Library as an example, this paper discusses the teaching mode, teaching philosophy, teaching design, teaching methods and contents in order to explore how embedded information literacy instruction can make use of the mobile Internet platform. The specific areas to be examined include teaching resources, enhancing classroom interactions, and after-class feed-pushing as part of teaching support. Finally, some recommendations are put forward for the extension and expansion of embedded information literacy instruction.
\end{abstract}

Keywords: Information Literacy, Embedded Instruction, Mobile Internet, University Library

\section{INTRODUCTION}

The term "information literacy" was originated by Paul Zurkowski, the president of the Information Industry Association (IIA), in his proposal to the National Commission on Libraries and Information Science (NCLIS) in 1974 (Behrens, 1994). Forest Woody Horton, an American information scientist, proposed in 1983 to design and offer information literacy courses (Horton, 1983). It has been over 40 years since the concept of "Information Literacy" was first suggested. With various changes over

\footnotetext{
1 This paper is one of the research project, "Practical Research on Mobile Information Literacy Education in University Libraries" (Project No.: 16BTQ006), funded by the National Social Science Fund of China.
} 
the years, information literacy instruction has undergone continuous development.

According to the revised Rules and Regulations on Libraries in Institutions of Higher Education (Ministry of Education of the People's Republic of China, 2016) released by the Ministry of Education of the People's Republic of China (hereinafter referred to as the "MOE of the PRC") on January 2016, "the academic libraries shall attach great importance to information literacy instruction, strengthen the development of systematic information literacy courses and seek improvements and innovations in freshman orientation and lectures by leverage of modern educational technologies." The revised version also specified that one of the top tasks for academic libraries is to carry out information literacy instruction. In July 2017, the Information Literacy Instruction Working Group, which is a subcommittee of the Steering Committee for Academic Libraries of China (SCAL) of the MOE of the PRC, issued The Guiding Opinions on Further Strengthening Information Literacy Instruction by the Institutions of Higher Education (Exposure Draft) (the Information Literacy Instruction Working Group of the Steering Committee for Academic Libraries of China (SCAL) of the MOE of the PRC, 2017) (hereinafter referred to as the "Guiding Opinions") to define that, "Embedded instruction is an educational form in which colleges and universities integrate information literacy instruction into their specialized courses or generalknowledge courses, thus improving students' professional information literacy with clearly pre-set targets, and this form of instruction usually requires the collaboration and coordination among different departments and administrations of the college or university. "The Guiding Opinions further prescribed that embedded instruction is one of the major forms of information literacy instruction employed by colleges and universities.

\section{LITERATURE REVIEW}

The earliest embedded instruction launched by both librarians and faculty members of international universities can be traced back as early as 1959, at Wayne State University of the United States of America. P. B. Knapp and other librarians collaborated with departments to conduct a pilot project, embedding library education in some academic courses (Knapp PB, 1963). In 1999, the Society of College, National and University Libraries (SCONUL), which represents all university libraries in the UK and Ireland, as well as national libraries and many of the UK's colleges of higher education, proposed in Information Skills in Higher Education (SCONUL, 1999) that "the development of the idea of 'information literacy' requires a collaborative and integrated approach to curriculum design and delivery based on close co-operation" between staff members and librarians. Meanwhile, the Association of College \& Research Libraries (ACRL), the largest division of the American Library Association (ALA), wrote in its Information Literacy Competency Standards for Higher Education (ACRL, 2000) that, "Integrated in the content, structure and system of subject curriculum, information literacy requires the cooperation among librarians, faculty members, and 
administrators." After that, the global practice of embedding information literacy instruction into a department-based curriculum had been carried out, and other influential practices include the Big6 Model of Information Problem-Solving (Eisenberg and Berkowitz, 1988), Problem Based Learning (Diekema, 2011), and coeducation by librarians and faculty (Belanger, 2012).

The earliest paper on Chinese universities' information literacy instruction was published in 1997 about the development of information literacy skills in university faculty (Yao, 1997). Li (2003) introduced the embedded information literacy instruction in university by analyzing the information literacy instruction courses in three universities in the United States and their experiences of creating these multi-campus, interdisciplinary and multi-institutional courses. Although the research on embedded information literacy instruction is not very extensive, the relevant research findings can be classified into four categories:

\section{1) International universities' embedded instruction}

The research on the practices of international universities' embedded information literacy instruction. The authors investigated the reasons for the prevalence of embedded information literacy instruction, including an exploration of various instruction models, target planning, instructional design, instruction methods, appraisal and evaluation systems, and online instruction. Gong (2010) analyzed international universities' cases and categorized three models of embedded information literacy instruction, which are Problem-based Learning (PBL), Discipline-based Online Information Literacy Instruction \& Guidance, and Multi-level and Multi-dimensional Embedding. She concluded that faculty members are the key to the success of embedded information literacy instruction, and librarians are important partners to faculty members. Gong also stated that differentiated embedding should be "student-centered". $\mathrm{Hu}$ and Peng (2011) revealed that the US universities they studied tended to adopt faceto-face classroom instruction while taking online instruction as a supplement. The authors further summarized some useful lessons that helped the universities with their embedded information literacy instruction, such as positive interactions between the librarians and the faculty members, good utilization of Internet-based instruction tools and placing emphasis on instruction assessment. Fu (2011) introduced the case of the University of West Florida's embedded information literacy instruction, in which she analyzed how it was embedded in academic courses, and how it also improved students' research capacities and information literacy skills. Xiong (2015) summarized some good practices of embedded information literacy instruction at several international universities, which included emphasizing target planning and instructional design; adopting student-centered PBL methods; establishing a reasonable appraisal and evaluation mechanism; and utilizing new information technology to support embedded information literacy instruction. Huang (2016) listed 3 reasons for the popularity of embedded information literacy instruction in Europe, America, and Australia, i.e., external reasons, internal advantages and promotion by the library industry. Huang also mentioned that the development of information technology exerted certain impacts on the models of information literacy instruction and that the co-instruction by librarians 
and faculty members has grown and matured via concerted efforts of developing online information literacy courses and drafting the guidance on embedded information literacy instruction. Wu et al. (2016) summarized 3 models of international universities' embedded information literacy instruction, i.e., embedded instruction by librarians alone, embedded instruction by both librarians and faculty members, and faculty members taking the leading role while librarians serve as teaching assistants. The instruction consisted of guidance on resource use and students' academic research. The effectiveness of the instruction was assessed using questionnaires. Wu was thus inspired that to create a successfully embedded information literacy instruction, librarians should carefully select a course as a pilot project, give special focus on students' feedback and learning evaluation results, and build cooperation with the school and its administrative departments. Zhou and Tang (2018) analyzed the achievements of embedded information literacy instruction of the University of Wisconsin and put forward some information literacy embedding strategies based on "meta literacy".

\section{2) Comparative studies on Chinese and international universities' embedded instruction}

The research on comparative case studies on Chinese and international universities' embedded instruction from the aspect of management mechanism, the ways of realization, instructional design, teaching research, incentive mechanism. Xie and Zhao (2012) sketched out the status quo of embedded information literacy instruction of Chinese and international universities and provided some enlightenment. These two researchers also pointed out that embedded instruction should be student-centered, and that librarians should proactively engage themselves in the classroom andonline embedded instruction.). Si et al. (2013) discussed typical cases of embedded instruction of some international universities, and summed up some reasons for their success, such as advanced teaching philosophy, abundant teaching resources, well-qualified librarians working on embedded instruction, effective communication and cooperation, as well as active popularizing and marketing. Zhang and Tu (2015)'s comparative study analyzed the embedded instruction of 15 famous Chinese and international universities from the perspectives of participants, management mechanisms, service facilities, implementation methods, and emotions.

\section{3) Chinese universities' embedded instruction}

The research on cases of Chinese universities' embedded instruction. Shenyang Normal University Library adopted Big6 to carry out embedded instruction. Thanks to faculty members and librarians' co-instruction, not only students' capabilities of searching, information reading comprehension, information expression, and communication have improved, but their awareness of being independent researchers has also increased (Hong \& Cui, 2008). Shanghai Jiao Tong University Library executed the embedded instruction in "flipped classes" and made certain achievements in quite a lot of information literacy embedded courses. The researchers involved also suggested some strategies to improve the effectiveness of embedded instruction, such as helping students to enhance their learning motivation, improving librarians' teaching abilities, strengthening software platform construction, technology application, and more 
(Huang et al., 2018). Capital Normal University Library's embedded information literacy instruction involved both librarians and faculty members under 2 models: one was led by the librarians and the other was led by the faculty members (Hu \& Peng, 2013). Zhang (2013), after analyzing the cases of the National Science Library and Harvard University Library, put forward that the "embedding" in embedded information literacy instruction was mainly reflected at four dimensions, i.e., targets, contents, environment, and mechanism. Also, Zhang made some suggestions like taking advantage of students' existing skills of using social media to change the status quo of teacher-centered teaching, providing a good environment and technical support through the collaborative mechanism, and increasing the interaction between teachers and students. In order to resolve the problems in embedded instruction, Chongqing University Library initiated an information literacy skills learning project which was composed of digital resources retrieval training, library resources utilization training, search engine usage training, and academic writing training. These four levels of training have been embedded into the whole process of a specialized information literacy instruction course (Zhang, Yang \& Yuan, 2015). Southeast University Library adopted both classroom and online embedded instruction throughout the entire instruction process to adapt itself to the Medical School's PBL (Tang, 2015). In the embedded instruction courses of Southeast University, the library collected and answers students' questions in real-time, analyzed the needs of teachers and students, and shared the solutions to the popular questions in the class group on social media, by using QQ Group (similar to MSN Chat Group), a blog, and more (Tang, 2015). Beijing Foreign Studies University Library embedded information literacy instruction into the generalknowledge courses designed for undergraduates. The researchers involved explored the contents, forms and methods of such embedding, and proposed some noteworthy issues (Zhou, 2016).

\section{4) Theoretical research on embedded instruction in China}

Theoretical research on embedded instruction in China, covering instruction models, environments, methods. Zhang (2013) conducted a literature review, and classified the embedded information literacy instruction in China and several other countries into four models: Course-Related Lectures, Scalable Model, Multi-level Teaching Based on Students' Capabilities, and End-to-End Library-faculty Cooperation. Based on "Collaborative Theory", Tang (2014) proposed that librarians and faculty members should jointly work on embedded information literacy instruction from four aspects: information exchange, information retrieval, content creation and information evaluation. Zhang (2015) analyzed the implementation approaches, instructional design, educational research and incentive mechanism, and further emphasized the significance of establishing an embedded instruction research team as well as research on course reform. Xiang (2014) advised that in the context of e-learning, the cooperative mechanism among librarians, faculty members, and relevant administrative departments should be established to support the development of universities' embedded instruction. The author also encouraged librarians to participate in embedded instruction related training to learn how to assess students' performance to evaluate the effectiveness and quality of instruction. Liu et al. (2016) adopted "Actor Network 
Theory" to analyze the operational mechanism of embedded information literacy instruction, and further proposed to improve embedded information literacy instruction theories by highlighting the core role of universities and benefits to all involved.

In summarizing the literature in the four categories of existing research on embedded information literacy instruction above, we learned that research on the influence of mobile/Internet developments on embedded instruction has seldom been examined.

A survey on information literacy instruction conducted among Chinese university libraries in 2015 indicates that $83.9 \%$ of 545 libraries have carried out freshman orientation, $91.5 \%$ of them have given series of lectures on information literacy, and $69.2 \%$ of them have provided credit-based courses. However, the survey also shows that only $17.8 \%$ of these libraries have tried embedded information literacy instruction, among which more than half have just one to three courses (Yue et al., 2016).

We initiated an online survey in March 2019 to look into the current situation of information literacy instruction in 42 "Double-First Class" universities in China. The results indicate that more than $90 \%$ of the universities have freshman orientation and lectures as the major form of information literacy instruction, and $76.2 \%$ offer credit courses, while only $16.7 \%$ implement embedded instruction. Both the literature review and the survey show that embedded instruction in China is still in a preliminary stage.

Table 1 Information literacy instruction in "Double-First Class" universities

\begin{tabular}{|l|l|l|l|l|}
\hline $\begin{array}{l}\text { Number of university } \\
\text { libraries }\end{array}$ & $\begin{array}{l}\text { Freshman } \\
\text { orientation }\end{array}$ & Lectures & $\begin{array}{l}\text { Credit } \\
\text { courses }\end{array}$ & $\begin{array}{l}\text { Embedding } \\
\text { teaching }\end{array}$ \\
\hline 42 & $92.9 \%$ & $97.6 \%$ & $76.2 \%$ & $16.7 \%$ \\
\hline
\end{tabular}

\section{RESEARCH METHODS}

The Information Literacy Instruction course of the East China Normal University (ECNU) was offered to students for the first time in 1997. Since 2006, librarians of ECNU have started trying to embed the information literacy instruction in some academic courses. Since 2013, ECNU started using mobile technology to support information literacy instruction. So far, the library has collaborated with more than ten departments of ECNU to conduct embedded information literacy instruction. In this paper, we will use the case study research method (Robert K. Yin, 2011) to study the teaching/learning practice of ECNU's department-based, embedded information literacy instruction. This paper seeks to address the following questions:

(1) How did the librarians explore the implementation of embedded information literacy instruction in ECNU?

(2) What pedagogical practices have the ECNU librarians tried in order to embed information literacy instruction in academic courses? 
(3) How is an embedded information literacy instruction class designed?

(4) How can information literacy instruction be embedded in the teaching and learning processes of academic courses?

(5) How can mobile technology be taken advantage of in order to support embedded information literacy instruction?

The purpose of this paper is to answer the questions above by studying the practice of ECNU's embedded information literacy instruction. We hope this paper will provide an example of the application of embedded information literacy instruction in higher education.

\section{CASE STUDY: EAST CHINA NORMAL UNIVERSITY ("ECNU")}

\section{Overview}

East China Normal University Library (hereinafter referred to as the "Library") carries out its information literacy instruction in 3 major ways: freshman orientation, lectures and courses, of which all involve collaboration with faculty members to some extent. After years of practice, the Library has built up some experience in information literacy instruction embedded courses.

Freshman orientation

Freshman orientation is a fundamental opportunity for information literacy instruction in guiding freshmen on how to use library resources, how to find the books they need, how to utilize abundant electronic resources, and more. The Library conducts freshman orientation in different ways, such as lectures, touring the Library, and through "The Beginner's Guide," a module that can be found both on the library website and its official WeChat account. The Library has explored three ways to collaborate with faculty members in terms of freshman orientation:

1) Giving lectures in the ECNU Library and arranging library tours according to department;

2) Enhancing students' general knowledge on library services, plus introducing specific collections and database(s) for a specific department/discipline;

3) Giving lectures in departments;

\section{Lectures}

Lectures consist of information literacy series, workshops, and database demonstrations given by database vendors. The Library provides customized workshops to different departments, and in each department, the students of the same major or same class could attend such workshops as a group. Both teachers and students are allowed to reserve such workshops, with workshop time, venue and contents to be further discussed and determined with the Library.

\section{Courses}

The Library has designed diversified information literacy courses targeting different student groups with different needs, including optional courses open to all 
undergraduates and postgraduates, as well as embedded department-based courses.

In terms of optional courses, the Library designed the course "Information Literacy" for undergraduates and awarded them one or two credits for this, with students of liberal arts and science attending separately. The instruction designed for postgraduates of liberal arts and science is entitled "Literature Research." It is worth mentioning that nevertheless, three classes were created for the liberal arts postgraduates each semester, and classrooms are completely full. As for lecture series, all teachers and students are welcome to attend, and undergraduates can obtain one credit for listening to these lectures.

See below for the information literacy instruction embedded into faculty courses.

\section{Instructional models}

The Library's pilot of embedding information literacy into faculty courses was launched in 2006. Starting from scratch and making progress step by step, the Library has been cooperating with more than ten departments under two models until now: one is led by faculty and the other by librarians.

Faculty taking the lead

In this model, faculty play a major role in librarian-faculty collaboration, integrating information literacy instruction into department-based specialized courses and liberal education. This involves many departments and institutes under the School of Social Development, School of Humanities and Social Science, School of Psychology and Cognitive Science, Faculty of Economics and Management, Faculty of Education Sciences, as well as Meng Xiancheng College, MBA Education Center, and the Executive Development Programs Center. Usually, librarians take one and a half to three hours to introduce the Library's resources, databases, etc. relating to the students' disciplines or majors, and guide them on how to acquire and utilize information.

Librarians taking the lead

In this model, the librarians play a major role in library-department collaboration, taking half of or entire course hours for information literacy instruction, which involves the School of Software Engineering and the School of Music.

Co-developed by librarians and teachers of the School of Software Engineering, "Academic Writing - Information Retrieval and Use," is a compulsory course for the undergraduates in their last year's study. The librarian takes half, of the hours $(0.5$ credits) to expound on related databases, to help students to improve their retrieval capability and literature research skills.

Co-developed by librarians and teachers of the School of Music, "Music Information Retrieval" is a compulsory course for first-year postgraduates of the School. The librarian concerned takes all of the course hours (two credits) to focus on information retrieval, assisting students in strengthening their information acquisition and analysis capabilities, and enhancing their awareness of maintaining academic standards. Information literacy instruction has also been embedded into generalknowledge courses for second-year postgraduates, guiding them on how to draft a thesis 
proposal via case analysis.

Exceptional embedded information literacy instruction

As an optional course, "Literature Research" attracts students from different schools and departments. Some students, after learning for some time, quickly become a "master" of information retrieval. Not only do they excel beyond their classmates who did not choose the course, but they also become supervisors' right hand with their search skills, leaving their classmates and supervisors impressed and amazed. Some students become "instructors" themselves after attending the class. For example, a doctoral student, who reported to her supervisor that the skills she had learned from the author's class were very helpful to her academic research, was requested by her supervisor to give her classmates a lecture themed "Database and Information Retrieval." In another example, a postgraduate, after taking the course Literature Research for two weeks was also given 20-30 minutes at her supervisor's class to share what she had learned from the author's class.

\section{Instructional design}

Teaching philosophy

"Education is not the filling of a pail, but the lighting of a fire."(Duszynski, 2008) In spite of limited hours for most information literacy instruction embedded courses, the authors hold that information literacy instruction is not to impart information retrieval knowledge to students, but for students to think about teaching, attach importance to students' grasp of ideas and methods, cultivate students' critical thinking and creativity, and stimulate their curiosity and desire to learn. The Library's mission is to make students realize information literacy is a powerful momentum to improve their learning capacity.

Pre-class preparation

For all the information literacy instruction embedded courses, either led by university teachers or by librarians, meticulous pre-class preparation is the key to success. The course led by faculty will be used as an example.

\section{1) Teaching contents}

For each course based on librarian-faculty collaboration, all lessons are prepared from scratch. At the end of the previous semester or before the start of a new semester, and during the first several weeks of a semester, librarians will have an in-depth discussion with the teachers of specialized courses or general-knowledge courses in order to determine the teaching content and hours in accordance with their course targets, plans, and outlines. Students' information literacy related questions are obtained in advance.

\section{2) Teaching supports}

Teaching supports mainly refers to teaching equipment, software, etc. In addition to common devices such as computers, a projector and Internet, it is requested that technical staff of the Library install a teaching software called "Rain Classroom" (Tsinghua University, 2016; please see the following paragraph for details about the software) on a specific computer, and remind students to take phones installed with the application "WeChat" to class. 
3) Rain Classroom, a teaching software used on mobile devices

In a mobile environment, students take mobile phones wherever they go. They use WeChat so frequently, that some cannot even keep from peeping at their phones in class. Considering these behaviors, we made an attempt to use "Rain Classroom" via mobile phones in 2017. "Rain Classroom" is a teaching tool created by MOOC-CN Education Investment Co., Ltd. founded by Tsinghua Holdings Co., Ltd. All the functions rely on PowerPoint and WeChat, which are easy and convenient to use. Only the teacher's computer needs to have it installed. After class begins, teachers open their PowerPoint to automatically create a QR code for students to scan to enter "Rain Classroom." Each page of PowerPoint will be simultaneously transmitted to students' mobile phones, which frees students from copying or taking photos, thus making them focus more on listening and thinking.

The interactive function of "Rain Classroom" makes teaching more efficient and provokes a surge in student participation. Teachers can send out questions and set a time limit for students to answer via mobile phones. After the time is up, teachers can check the answers conveniently. Students can raise any queries and doubts through "Rain Classroom." They can also send pictures or messages to teachers' mobile phones for teachers to promptly check, save or show to the whole class through the projector.

There are three main types of exercises in the "Rain Classroom:"

1) Polls: Polls consist of one-choice questions and multiple-choice questions. There is no right or wrong answer in a poll, so students will not have the pressure of giving the correct answer.

2) Multiple Choice: Multiple choice questions consist of single-answer questions and multiple-answer questions, and students are expected to select only correct answers from the choices offered.

3) Open Question: Open questions invite students to demonstrate their understanding and there is no right or wrong answer in an open question.

Classroom teaching

Classroom teaching is used to highlight knowledge points, while summarizing and refining thoughts and methods through these points. The major steps of classroom teaching are as follows:

Step 1: warm-up

1) Display the questions collected before class and tell students today's target is to answer them; select good questions to start the class and arouse students' interests.

2) Send an exercise or exercises (polls or multiple choice questions) to students' mobile phones and set a time limit such as 1-2 minutes, to understand students' information literacy level.

3) Discuss key points and difficulties to trigger students' thinking.

Step 2: Explanation and summarization

Our teaching contents are mainly composed of three factors: 
1) Discipline related information retrieval and use, including the Library's resources (databases and collections), and use of search engines;

2) Information analysis and evaluation;

3) Academic writing and maintenance of academic standards.

The above contents are expounded via case sharing, unfolding all the details before making a summary. Covering the questions raised by students or teachers, the cases are not only closely related to general-knowledge or specialized courses embedded with information literacy, but also factor in the needs and characteristics of students of different types and abilities. For instance,

1) To postgraduates and doctoral students, our cases try to reveal the train of thought to do literature research for a thesis/dissertation proposal.

2) To the junior and senior students, our cases focus more on the major sources of academic information, i.e. databases, and on the differences between databases and search engines. Meanwhile, some interesting cases catering to undergraduates are also displayed, such as a case on how to use effective search methods to find information about studying abroad or job-hunting. Another case was presented on how a senior was guided to search and screen recruitment information, lock work scope by analyzing his major, industry, and location, etc., and finally received some offers.

3) To freshmen and sophomores taking information literacy instruction embedded general-knowledge courses on science and technology innovation, after finding that some students' projects are related to mobile Internet, we added the contents on how to acquire information and use the library, etc. through mobile devices.

Quizzes are inserted throughout the case sharing process, and students have 12 minutes to answer each of them. Quizzes throughout the class help students to keep their attention focused while providing both teachers and students a chance to assess how well students have acquired the knowledge they just learned.

All in all, this teaching is not simply a general introduction to universal search knowledge. Instead, every effort is taken to make faculty members and students feel that we have a thorough grasp of their discipline's features and their real needs, and what we offer is a customized course especially for them. In the meantime, it is anticipated that students understand the class to be "informative" and that they really can learn something. We guide students to sum up methods and ideas from cases and questions, then make analyses and summarizations. Next the whole retrieval process is clarified, thus leaving students inspired and enlightened.

Step 3: Provoking thoughts

1) Before the class is dismissed, send an exercise or exercises (polls or open questions) to students and they will have 2-3 minutes to finish it/them with the "Rain Classroom" on their mobile devices. The goal is to obtain students' comments and feedback. 
2) Besides sending exercises via "Rain Classroom," teachers can leave open questions as homework to provoke students' deeper thinking and stimulate their curiosity about information literacy knowledge.

During the class, students can press the "unclear" button on the corresponding slide(s) of the PPT file whenever they need more explanation about the content, so the teacher can adjust the pace of teaching based on students' feedback.

During the whole class, there is an attempt to keep balance by providing enough information while leaving time for students to think. Answering questions via mobile phones is very popular among students, as they are more willing to interact with teachers in this way.

Review and follow-up

After class, we continue to adjust and improve the design of classroom teaching by reflecting on classroom observation, reviewing feedback from faculty and students, and analyzing the data on students' participation, their answers to exercises, etc. via "Rain Classroom."

What's more, video clips, voice messages, pictures, documents, and other materials are sent to faculty members and students via "Rain Classroom" for their information or further study. They can check these materials on their cell phones at any time, which is a beneficial supplement to classroom teaching.

Librarians also keep close communication with faculty members by "WeChat" and join the students" "WeChat" group to follow up with their needs. For instance, with the author's help, an undergraduate who had planned to write a term paper about "Machu Picchu" found some rare research findings, on which he wrote his paper and became the only student who got an " $A$ " in his class. Another undergraduate majoring in music wanted to study the representative works of Aaron Avshalomov (1894-1964), a Russian-born Jewish composer, but got stuck due to not being able to find musical scores. Together with the author, she tried again and again for three and a half months. Finally, she discovered that the Free Library of Philadelphia had the musical score. After resolving copyright issues, she became the only one in China who has ever seen it, thus completing her thesis as "unique" research in China.

Unexpected achievement

Information literacy instruction based on librarian-faculty collaboration is not only "coteaching", but also an engine for faculty members to improve their academic research capacity. For the faculty members who had attended the author's information literacy course along with students, the author followed up on their teaching and academic activities, cleared up their doubts and confusion in information retrieval, and discussed with them better retrieval strategy. Thanks to the solid foundation resulting from more comprehensive literature research, a couple of teachers successfully initiated some national research projects. For example, a teacher of the Faculty of Education Sciences won some research projects at national or Shanghai Municipality level. Another teacher of the Faculty of Economics and Management won a Young Scholar's Project 
sponsored by the National Social Science Fund of China.

\section{REFLECTION AND RECOMMENDATIONS}

It's concluded that there are three major problems in universities' embedding information literacy instruction into faculty courses:

1) Being proactive in advancing information literacy instruction based on librarian-faculty collaboration, librarians find it difficult to get an entry point or to meet teachers/students' real needs. Related publicity by libraries cannot be effectively conveyed, so teachers and students lack interest due to limited understanding.

2) Despite the fact that both faculty members and students have a strong desire for high-quality academic information, they struggle with searching for valuable information on their own, without knowing how to improve information retrieval skills effectively, or that libraries already have information literacy courses.

3) Last but not least is, are the librarians qualified enough to teach information literacy courses? Could they win the trust of teachers in specialized courses? Based on the Library's exploration and practices during the past dozens of years, the authors made some reflections and recommendations as follows.

\section{Formulating and improving relevant policies}

The Guiding Opinions mentioned in the literature review specified several major forms of information literacy instruction, i.e., credit courses, information literacy instruction embedded courses, lectures, and workshops. It also specified that one of the top tasks for academic libraries is to carry out information literacy instruction. We do anticipate that the draft of Guiding Opinions (still in the stage of soliciting comments), could be finalized and released very soon, thus providing a legal basis for further implementation of librarian-faculty collaboration based information literacy instruction.

\section{Cooperating with university administrators and faculty members}

The Guiding Opinions also pointed out information literacy instruction embedded into department-based courses requires the cooperation and collaboration of multiple parties, including administrative departments such as the Office of Academic Affairs, Administration of Postgraduate School, as well as all departments and libraries, with each party taking their own responsibilities: librarians to carry out diversified information literacy instruction (including that which is embedded into faculty courses), the administrative departments to coordinate the parties involved, and departments to incorporate information literacy into their curriculum plans.

\section{Encouraging librarians to explore and innovate}

For libraries, collaborating with university administrators and faculty members requires policy support and guidance. However, top-to-down collaboration is not the only means to carry out embedded information literacy instruction. The information literacy librarian explores their individuality, gives full play to their advantages, and finds the 
entry point for cooperation from multiple perspectives. For example, after the author taught the optional postgraduate course "Literature Research" for years, the course has drawn so many students and teachers of ECNU or those from other universities to audit. Considering the popularity among teachers and students, some faculty members and departments took the initiative to contact the author for cooperation.

\section{Incorporating into teaching and study}

University teachers and students have a strong desire to search for academic information. Information literacy instruction should be based on different needs and be incorporated into the end-to-end process of research, teaching and study. It should cover the teachers who would like to apply for sponsoring research projects, undergraduates who participate in scientific innovation programs, postgraduates and doctoral students who draft proposals for theses/dissertations, all the students about to graduate or looking for foreign supervisors to continue their study abroad, etc. If all these needs could be satisfied with our information literacy instruction, this would be a great accomplishment.

\section{Utilizing new technology to support teaching}

Class hours for information literacy instruction are limited, so we have all reasons to apply new technology to improve teaching efficiency and effectiveness. For example, we could use an online teaching platform such as "Blackboard" on PC, and its mobile version has been recently launched. The "Rain Classroom," a teaching software for mobile devices, has been widely applied to classroom teaching by many university teachers, including librarians. To faculty members and students who attend the Library's class, it is a novel, impressive, interesting and useful tool, allowing them to study teaching contents before and after class; to us, we are so amazed to see the teaching results it has helped us to achieve. For instance, a student said, "I think the 'Rain Classroom' introduced a new way of teacher-student interaction into the classroom". A survey taken in the Science \& Technology Innovation course of Da Xia College has shown that $42.9 \%$ of students were very satisfied with the performance of the "Rain Classroom" and $54.2 \%$ of students have rated somewhat satisfied. In total, $97.1 \%$ of students in the Science \& Technology Innovation course of Da Xia College were satisfied with the "Rain Classroom."

Though new technology tools, such as the "Rain Classroom" can enhance student learning, they are not the solutions to all the problems in the process of teaching and learning. We think educational philosophy and teaching content play more crucial roles in teaching and learning than technology, while technology could be a useful tool to improve the effectiveness of teaching and learning.

\section{References}

ACRL. (2000). Information Literacy Competency Standards for Higher Education. https://alair.ala.org/handle/11213/7668 Accessed 16 April 2019

Behrens, S. J. (1994). A Conceptual Analysis and Historical Overview of Information 
Literacy. College \& Research Libraries, 55(4): 309-322.

Belanger, J., Bliquez, R., \& Mondal, S. (2012). Developing a collaborative facultylibrarian information literacy assessment project. Library Review, 61(2): 68-91.

Diekema, A. R., Holliday, W., \& Leary, H. (2011). Re-framing information literacy: Problem-based learning as informed learning. Library and Information Science Research, 33(4): 261-268.

Duszynski, D. W. (2008). Acceptance of the Clark P. Read Mentor Award: Students, Opportunity, Serendipity, and WB Yeats: "Education is Not the Filling of a Pail; It is the Lighting of a Fire". Journal of Parasitology, 94(6), 1202-1209.

Eisenberg, M. \& Berkowitz, B. (n.d.). Big6. https://thebig6.org/ Accessed 16 August 2019

Fu, Q. (2011). A Case Study on Information literacy instruction Embedded in Specialized Course. Library Work and Study, (4):89-92.

Gong, F. (2010). The Reflection and Revelation of Foreign Colleges Information literacy instruction "embedded instruction mode". Library Tribune, (3):147-149+178.

Hong, Y. \& Cui, H. (2008). Application of Big6 to Carry out Embedding Teaching Service. Journal of Library Science, (4):87-89.

Hong, Y., Fu, Y., Du, H., \& Hu, Y. (2016). Investigation and Analysis of the University Library Information literacy instruction. Journal of Academic Libraries, (6):90-99.

Horton, F. W. (1983). Information literacy vs. computer literacy. Bulletin of the American Society for Information Science, 9(4): 14-16.

Hu, F. \& Peng, Y. (2011). Research on the Practice and Enlightenment of Integrated Information literacy instruction in American University Libraries. Library Development, (12):79-82.

Hu, F. \& Peng, Y. (2013). Study on the Practice of Subject Librarians and Faculties' Cooperation in Information literacy instruction. Library Work and Study, (3):95-98.

Huang, P. (2016). An Analysis on the Causes for the Prevalence of the Embedded Information literacy instruction in Europe, America and Australia. Library Work in Colleges and Universities, (2):55-60.

Huang, Q., Gao, X., Chen, Z., Ma, L., \& Chen, Y. (2018). Practical Exploration and the Enlightenment of Academic Libraries' Embedded Instruction on Flipped Class-Taking Shanghai Jiao Tong University as an example. Library and Information Service, 2018 (07):30-37.

Knapp, P. B. (1963). An experiment in coordination between teaching and library staff for changing student use of university library resources. International journal of dermatology, 21(4):208-215.

Li, X. (2003). Implementation and Analysis of American Universities' Information literacy instruction Programs. Journal of Library Science in China, (2):75-78. 
Liu, Y., Zhao, Y., \& Zhu, Q. (2016). Analysis of Embedded Information literacy instruction Operating Mechanism from the Perspective of Actor-network Theory. Library and Information Service, (18):35-42+70.

Ministry of Education of the People's Republic of China. (January 4, 2016). Notice of the Ministry of Education on Printing Rules and Regulation on Libraries in Institutions of Higher Education.

http://www.moe.edu.cn/srcsite/A08/moe 736/s3886/201601/t20160120 228487.html Accessed 16 April 2019

SCONUL. (1999). Information skills in higher education: Briefing Paper. http://www.sconul.ac.uk/sites/default/files/documents/Seven_pillars2.pdf Accessed 16 April 2019

Si, L., Wu, F., Qian, Q., Zhuang, X., \& Wong, S.. (2013). The Success Factors of Embedded University Library Service in Teaching. Library Journal, (3):50-54.

Tang, Q. (2015). The Practice of PBL Based Information literacy instruction Embedded instruction. Library and Information Service, (S1):222-225.

Tang, Y. (2014). Research on Collaborative Information Behaviors Between Subject Librarians and Professional Teachers. Library Development, (10):75-79.

Tongji University Library. (November 19, 2017). The Guiding Opinions on Further Strengthening Information literacy instruction by the Institutions of Higher Education (Exposure Draft). http://www.lib.tongji.edu.cn/ile/data/Guidance20171119.pdf

Accessed 16 April 2019

Tsinghua University. (June 17, 2016). MOOC-CN Education Investment Co., Ltd Launched a Wisdom Teaching Tool - Rain Classroom.

http://news.tsinghua.edu.cn/publish/thunews/9660/2016/20160617101758935397134/ 20160617101758935397134_html Accessed 16 April 2019

Wu, Y., Pu, Y., \& Zhao, R. (2016). Current Status and Implication of the Research on Embedded instruction in Foreign Academic Libraries. Library Development, (6):33-38.

Xiang, Y. (2014). Research on the Academic Library Service to the Embedded Instruction Based on E-learning. New Century Library, (11):18-20.

Xie, S. \& Zhao, W. (2012). Embedding-type Information literacy instruction: A New Way of Information literacy instruction. Information and Documentation Services, (1):108-111.

Xiong, H. (2015). Embedded Instruction Service in Academic Libraries Abroad: Practice and Inspiration. Library and Information Service, (17):67-72.

Yao, Q. (1997). A Preliminary Discussion on the Training of University Teachers' Information Accomplishment. Bulletin of Medical Library, (1):8-9.

Yin, R. K. (2011). Applications of Case Study Research. SAGE Publications

Zhang, B. (2015). Embedded instruction Research Based on Information literacy instruction. Journal of Modern Information, (10):147-150. 
Zhang, J., Yang, X., \& Yuan, G. (2015). Research and Practice of Integrated Information Literacy Training for Specialty Comprehensive Curriculum Design. Library and Information Service, (8):59-64.

Zhang, W. \& Yu, W. (2015). Comparative Research on Embedded instruction Service of Chinese Academic Libraries and Overseas Academic Libraries. Library Work in Colleges and Universities, (3):67-71.

Zhang, D. (2013). Embedded Information Literacy Service. Library and Information Service, (22):23-30.

Zhang, Y. (2013). Research Review on Instructional Model by Integrating Information Literacy in the Class Learning and Teaching Processes. Library Tribune, (3):175-178.

Zhou, J. (2016). Recent Development of Research, Inspiration and Application on Embedded Librarianship - A Case Study of Beijing Foreign Studies University Library. Journal of Academic Libraries, (6):56-62.

Zhou, Q. \& Tang, Q. (2018). Research on the Strategy of the Embedded Information Literacy - A Case Study of the University of Wisconsin System Flex Degree. Research on Library Science, (4):21-25.

\footnotetext{
About the authors

Guo Jinchi is Associate Research Librarian in the Reference Department of East China Normal University Library, Shanghai, China. Her research interests include information retrieval, information literacy, information consultation, information technology, and social media. She has published a monograph and a number of articles in journals and conference proceedings, such as Libri, Library Trends. She also teaches a graduate course "Information Retrieval." Currently, she is chairing a project funded by the National Social Science Fund of China. She can be reached at jcguo@library.ecnu.edu.cn
}

Zhu Han is Librarian in the Digital Department of East China Normal University Library, Shanghai, China. Her research interests include information organization and information retrieval. She has published a number of articles in journals. She is participating in a project funded by the National Social Science Fund of China. She can be reached at hzhu@library.ecnu.edu.cn.

*Han Zhu is the corresponding author. 